\title{
荧光增强型次氯酸根传感器及其在细胞成像与自来水检测中的应用
}

\author{
程晓红 ${ }^{*}, a$ 李 爽 ${ }^{b}$ 汪竞阳 ${ }^{a}$ 李望南 ${ }^{a}$ \\ $\left({ }^{a}\right.$ 湖北文理学院 低维光电材料与器件湖北省重点实验室 湖北襄阳 441053)

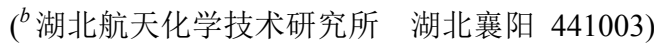

\begin{abstract}
摘要 报道了两个基于香豆素的苂光探针 $\mathbf{C 1}$ 和 $\mathbf{C 2}$, 对次氯酸根均表现出快速的苂光增强响应. 尤其是, 在化合物 $\mathbf{C 2}$ 的溶液中加入次氯酸根后, 溶液的苂光发射强度增大了 85 倍, 对次氯酸根的检出限低达 $1.8 \times 10^{-7} \mathrm{~mol} / \mathrm{L}$. 利用次氯酸 根独特的氧化性, 化合物 $\mathbf{C} 2$ 可实现对次氯酸根的高选择性识别, 对其他阴离子及氧化物则几乎无响应. 重要的是, 化 合物 $\mathbf{C 2}$ 可穿透细胞膜, 用于 HeLa 细胞中次氯酸根的苂光成像. 此外, 探针 $\mathbf{C} 2$ 还可用于自来水样中次氯酸根的检测. 关键词 荧光探针; 次氯酸根; 水溶性; 生物成像
\end{abstract}

\section{"Turn-On" Fluorescent Probe for Hypochlorite: Successful Bioimaging and Real Application in Tap Water}

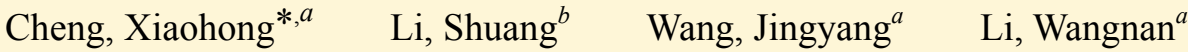 \\ ( ${ }^{a}$ Hubei Key Laboratory of Low Dimensional Optoelectronic Materials and Devices, \\ Hubei University of Arts and Science, Xiangyang, Hubei 441053) \\ ( ${ }^{b}$ Hubei Institute of Aerospace Chemical Technology, Xiangyang, Hubei 441003)
}

\begin{abstract}
Taking advantage of the special oxidation property of hypochlorite, two novel coumarin-type fluorescent probes $\mathbf{C 1}$ and $\mathbf{C 2}$ were synthesized for $\mathrm{ClO}^{-}$detection. Both probes could detect $\mathrm{ClO}^{-}$anions in aqueous solution efficiently with rapid switching-on fluorescent methods. Especially, probe $\mathbf{C 2}$ displayed dramatic enhancement in fluorescence emission spectra with the detection limit of $1.8 \times 10^{-7} \mathrm{~mol} / \mathrm{L}$. In addition to its high selectivity for $\mathrm{ClO}^{-}$rather than other common anions and reactive oxygen species, $\mathbf{C 2}$ was successfully applied to the bioimaging in HeLa cells with 'turn-on' fluorescent methods. Moreover, probe $\mathbf{C 2}$ could be used for the analysis of $\mathrm{ClO}^{-}$levels in tap water and potentially in environmental samples.
\end{abstract}

Keywords fluorescent probe; hypochlorite; good solubility; bioimaging application

\section{Introduction}

Recently, the real-time detection for hypochlorite with high sensitivity and selectivity has aroused extensive attention due to the fact that it is implicated in a variety of pathological diseases (such as atherosclerosis, neuron degeneration, cystic fibrosis, arthritis, and cancers) on the one hand ${ }^{[1]}$ and is widely used in the household bleach, disinfection of drinking water and cool-water treatment on the other. ${ }^{[2]}$ Therefore, a number of fluorescent probes for $\mathrm{HClO}$ detection have been exploited taking advantages of the strong oxidative ability of $\mathrm{HClO}$ towards specific recognition sites, ${ }^{[3]}$ including chalcogenide atoms of $\mathrm{S} / \mathrm{Se} /$ $\mathrm{Te}, N$-containing hydrazine/oxime/hydrazone/Schiff bases, unsaturated $\mathrm{C}=\mathrm{C}$ bond, $p$-methoxyphenol $/ p$-methoxyaniline and other groups. For practical applications, probes with fluorescence "turn-on" signals in the presence of analytes are superior to those with "turn-off" response which may be significantly influenced by some background factors. ${ }^{[4]}$ However, the design of small molecule-based probes with fluorescence enhancement response is still challenging.

In this work, we expected to obtain novel "switching-on" probe for $\mathrm{ClO}^{-}$detection by utilizing its unique oxidative ability. Compounds $\mathbf{C} 1$ and $\mathbf{C 2}$ were designed and synthesized, which were composed of a coumarin dye and an oxime protective group as the recognition unit

* Corresponding author. E-mail: chengxiaohong0807@126.com.

Received March 13, 2020; revised April 12, 2020; published online May 11, 2020.

Project supported by the Natural Science Foundation of Hubei Province (No. 2018CFB454), the Project of Hubei University of Arts and Science (No. XK2020042) and the Teachers' Scientific Ability Cultivation Foundation of Hubei University of Arts and Science (No. 2020kypyfy031).

湖北省自然科学基金(No. 2018CFB454)、湖北文理学院学科开放基金(No. XK2020042)、湖北文理学院教师科研能力培育基金(No. 2020kypyfy031)资 助项目. 
(Scheme 1). It was expected that the oxime protective group could be removed by $\mathrm{ClO}^{-}$to liberate the aldehyde group, accompanying with the "off-on" signal. Herein, we would like to describe the synthesis and the spectroscopic evaluation of the new fluorescent probes toward hypochlorite in detail, featuring advantages such as easy-tomake, good solubility, switching-on signal changes, high sensitivity, rapid response, as well as the successful practical application in bioimaging and tap water.

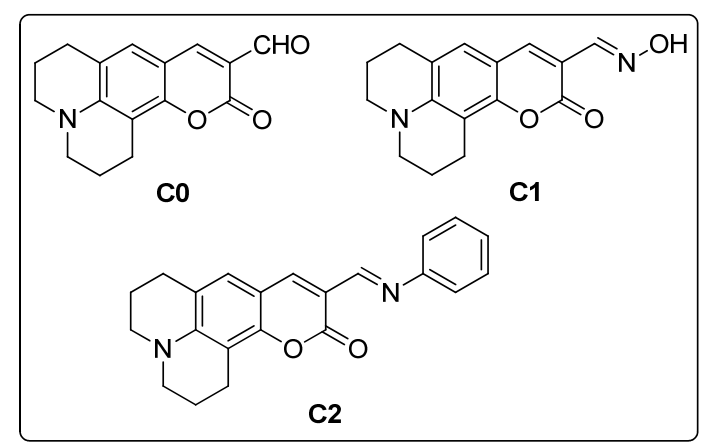

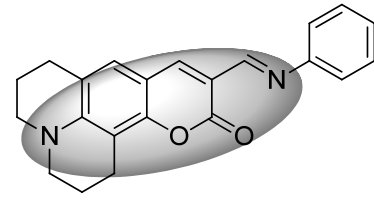

Non-fluorescent

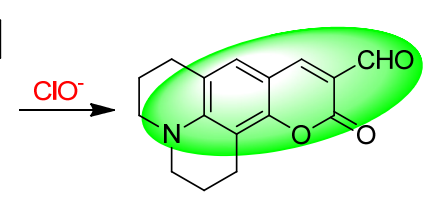

Strongly-fluorescent
Scheme 1 Structures of compounds C0, C1 and C2 and the sensing process

\section{Results and discussion}

\subsection{Synthesis and structural characterization}

The synthetic route to compounds $\mathbf{C 0}, \mathbf{C 1}$ and $\mathbf{C 2}$ was depicted in Scheme 2. It was easily seen that the target compounds were prepared conveniently through the general nucleophilic addition between aldehyde $\mathbf{C O}$ and amino, following the similar procedure in the reported literature. The whole synthetic route was simple and the purification was easy. Target compounds $\mathbf{C 1}$ and $\mathbf{C 2}$ exhibited good solubility in common organic solvents, such as acetone, $N, N$-dimethylformamide (DMF), dimethyl sulfoxide (DMSO), $\mathrm{CH}_{3} \mathrm{CN}$, and tetrahydrofuran (THF). Their structures were well characterized by ${ }^{1} \mathrm{H} \mathrm{NMR},{ }^{13} \mathrm{C} \mathrm{NMR}$, ESI-MS and elemental analysis, and all gave satisfactory spectral data.

\subsection{Optical properties of compounds $\mathrm{C} 1$ and $\mathrm{C} 2$}

Before the sensing experiments, the photoluminescence behaviors of compounds $\mathbf{C} 1$ and $\mathbf{C 2}$ were firstly examined. With the addition of water into DMSO solution (with final concentrations kept unchanged at $10 \mu \mathrm{mol} / \mathrm{L}$ ), the fluorescent intensity of $\mathbf{C 1}$ was gradually enhanced. Differently from compound $\mathbf{C 1}$, the DMSO solution of $\mathbf{C 2}$ was strongly luminescent. However, when different amounts of water were added, the emission spectra decreased greatly: the resultant mixture became nearly non-fluorescent with
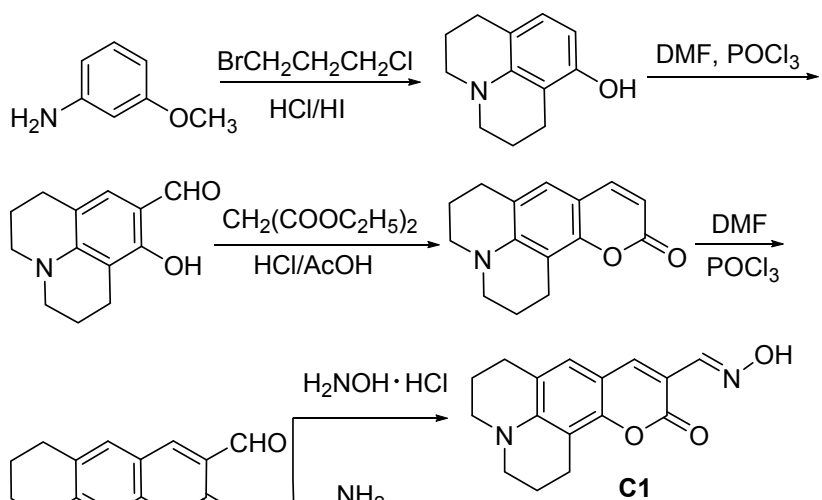

co

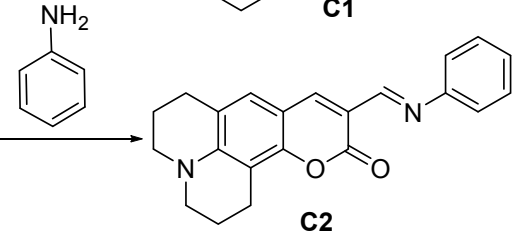

Scheme 2 Synthetic route of compounds C0, C1 and C2

the quantum yield of only $c a$. $2 \%$ upon the addition of $90 \%$ $\mathrm{H}_{2} \mathrm{O}$. As we know, with the increasing amount of water, the solubility of organic compounds $\mathbf{C 1}$ and $\mathbf{C 2}$ became poor, and more molecules existed as aggregate state. As to compound $\mathbf{C 1}$, its light emission was further enhanced by aggregate formation, which was similar to the AIEE-active (aggregation-induced emission enhancement, AIEE) chromophoric materials reported by Tang et al. ${ }^{[5]}$ While in the case of compound $\mathbf{C 2}$, an emissive material was induced to non-emission by aggregation, consistently with the normal aggregation-caused quenching (ACQ) molecules. The different photoluminescence behaviors between compounds C1 and C2 were possibly ascribed to their different solubility and different size of the rotor (hydroxyl in $\mathbf{C 1}$ and phenyl group in C2), which were consistent with the reported literature. ${ }^{[6]}$ In terms of aldehyde $\mathbf{C 0}$, the emission spectra shifted only from $508 \mathrm{~nm}$ to $512 \mathrm{~nm}$ with the addition of $10 \%$ water. However, the intensity kept almost stable with continuous increasing of $\mathrm{H}_{2} \mathrm{O}$.

Considering the practical application, 2-(4-(2-hydroxyethyl)-1-piperazinyl)ethanesulfonic acid (HEPES) buffer (containing 10\% DMSO) was chosen as the sensing medium. The aqueous solution itself of $\mathbf{C 1}$ was relatively emissive, which was not beneficial to the production of a high signal output during detection process. Through subtle adjustments to the structure, compound $\mathbf{C 2}$ was designed and expected to efficiently sense $\mathrm{ClO}^{-}$with off-on response. Comparatively, it was apparent that in the sensing medium, the transformation from compound $\mathbf{C 2}$ to aldehyde CO would induce remarkable enhancement of emission intensity, which would be beneficial to the design of "switching-on" fluorescence probe.

\subsection{Sensing properties of $\mathrm{C} 1$ toward $\mathrm{ClO}^{-}$}

Firstly, the sensing properties of $\mathbf{C 1}$ in response to $\mathrm{ClO}^{-}$ were investigated and $10 \mathrm{mmol} / \mathrm{L}$ HEPES buffer ( $\mathrm{pH} 7.4$ ) containing $10 \%$ DMSO was chosen as the reaction medium. We tried to add $\mathrm{ClO}^{-}$into the diluted solution of ox- 
imes C1 (Figure 1), immediately, the emission spectra displayed significant enhancement even with the concentration of $\mathrm{ClO}^{-}$as low as $2 \mu \mathrm{mol} / \mathrm{L}$. With the increase of $\mathrm{ClO}^{-}$concentration in the test system, the intensity centered at $c a .510 \mathrm{~nm}$ increased correspondingly. When 20 $\mu \mathrm{mol} / \mathrm{L} \mathrm{ClO}^{-}$was added, the emission intensity reached the maximum with remarkable enhancement. To see the results more visually, we summarized the emission intensity changes as a function of $\mathrm{ClO}^{-}$concentrations. As demonstrated in the inset of Figure 1, in the range of $0 \sim 20$ $\mu \mathrm{mol} / \mathrm{L}$, there was a nearly linear relationship between the intensity change and the concentration of $\mathrm{ClO}^{-}$, which was beneficial to the detection of $\mathrm{ClO}^{-}$quantitatively.

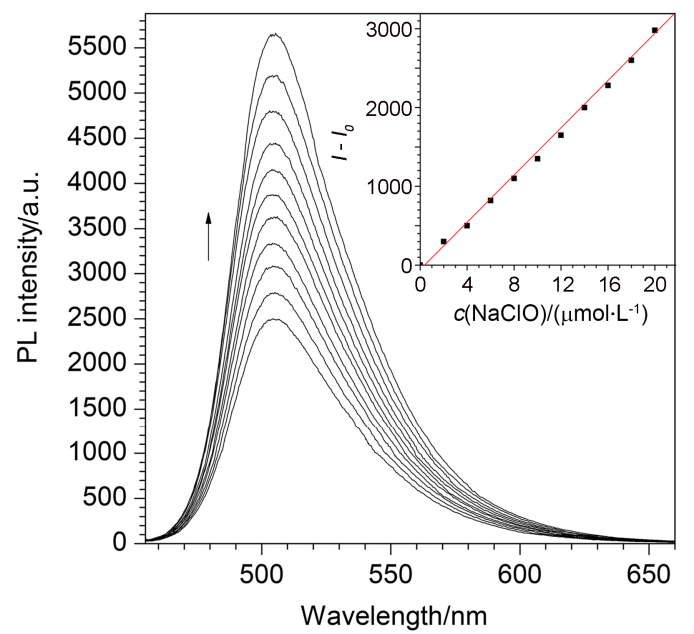

Figure 1 Fluorescent emission spectra of $\mathbf{C 1}(10 \mu \mathrm{mol} / \mathrm{L}$, in $\left.\mathrm{DMSO} / \mathrm{H}_{2} \mathrm{O}, V: V=1: 9\right)$ in the presence of different concentrations of $\mathrm{NaClO}$ excited at $430 \mathrm{~nm}$

Fom bottom to top: $0.0,2.0,4.0,6.0,8.0,10.0,12.0,14.0,16.0,18.0$ and $20.0 \mu \mathrm{mol} / \mathrm{L} \mathrm{ClO}^{-}$. Inset: plot of fluorescent intensity at $510 \mathrm{~nm}$ of $\mathbf{C 1}$ as a function of the concentration of $\mathrm{ClO}$

\subsection{Sensing properties of $\mathrm{C} 2$ toward $\mathrm{ClO}^{-}$}

Firstly, the effect of $\mathrm{pH}$ values on the emission spectra of $\mathbf{C 2}$ and $\mathbf{C 2}+\mathrm{ClO}^{-}$was investigated. It was obvious that the detection of $\mathbf{C 2}$ for $\mathrm{ClO}^{-}$could be operated in a wide $\mathrm{pH}$ range of $3.0 \sim 10.0$. In the titration experiment, the $\mathrm{pH} 7.4$ was chosen by using the HEPES buffer for the purpose of physiological application. Consequently, the sensing property of $\mathbf{C 2}$ in response to $\mathrm{ClO}^{-}$was investigated under this condition (DMSO/ HEPES, $V: V=1: 9$, $\mathrm{pH}$ 7.4). As shown in Figure 2, the emission intensity at $510 \mathrm{~nm}$ increased immediately to about 3 times of the original one with the addition of $\mathrm{ClO}^{-}$as low as 0.3 $\mu \mathrm{mol} / \mathrm{L}$. When $18.0 \mu \mathrm{mol} / \mathrm{L} \mathrm{ClO}^{-}$was added, the emission intensity reached its peak with about 85 -fold enhancement $\left(I / I_{0}-1\right)$. With continuous increase of $\mathrm{ClO}^{-}$in the test system, the fluorescence quantum yield increased from 0.02 to 0.73 . Meanwhile, the emission profile became gradually similar to that of its precursor, namely, aldehyde C0. Furthermore, there was a nearly linear relationship between the intensity change and the $\mathrm{ClO}^{-}$concentration as demonstrated in the plot of Figure 2. The detection limit of probe $\mathbf{C} 2$ was evaluated based on the above fluores- cence titration and then calculated with the following equation: detection limit $=3 \sigma / k^{[7]}$. Where $\sigma$ is the standard deviation of blank measurement acquired by ten times measurement of emission spectrum of $\mathbf{C 2}$, and $k$ is the slope from the inset plot in Figure 2. Accordingly, the detection limit of probe $\mathbf{C 2}$ was calculated to be as low as $1.8 \times 10^{-7} \mathrm{~mol} / \mathrm{L}$. Actually, the fluorescence difference of $\mathrm{C2}$ before and after the addition of $\mathrm{ClO}^{-}$could be easily distinguished by naked eyes. As displayed in the inset of Figure 2, the solution changed from non-emission to strongly green fluorescence with the aid of a normal UV lamp. Thus, these results indicated that upon the addition of $\mathrm{ClO}^{-}$, the hypochlorite-promoted oxidation reaction of imine $\mathbf{C 2}$ really occurred as expected, and the precursor aldehyde $\mathbf{C O}$ was formed step by step. As shown in Figures 1 and 2, with the addition of same concentration of $\mathrm{ClO}^{-}$ anions $(2 \mu \mathrm{mol} / \mathrm{L})$, the fluorescent intensity of $\mathbf{C 2}$ at 510 $\mathrm{nm}$ increased by $\mathrm{ca}$. 12 times of the original one while that of $\mathbf{C 1}$ increased by 0.18 times only. Furthermore, with the addition of $18 \mu \mathrm{mol} / \mathrm{L} \mathrm{ClO}^{-}$anions, the fluorescent intensity at $510 \mathrm{~nm}$ increased by 85 and 1.28 times of the original one for $\mathbf{C 2}$ and $\mathbf{C 1}$, respectively. Therefore, comparing their sensing performance toward $\mathrm{NaClO}$, it was obvious that $\mathbf{C} 2$ had much higher sensitivity than $\mathbf{C 1}$.

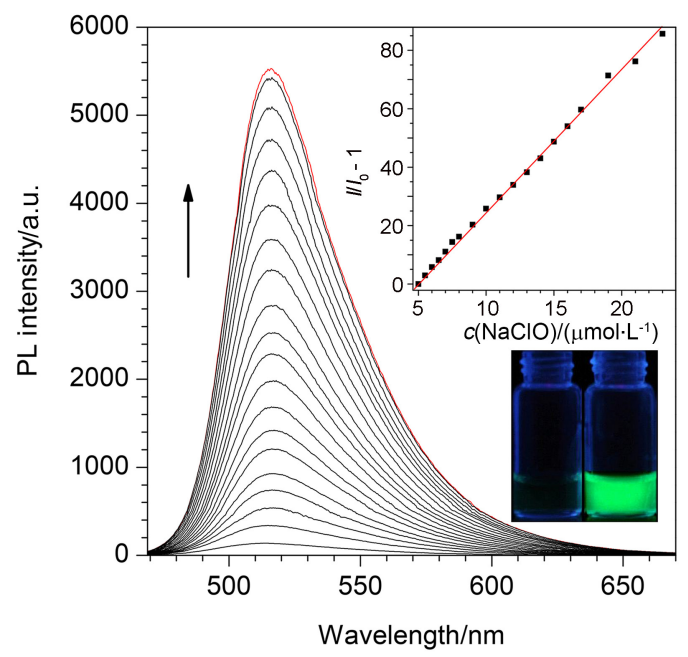

Figure 2 Fluorescent emission spectra of $\mathbf{C 2}(10 \mu \mathrm{mol} / \mathrm{L}$, in $\left.\mathrm{DMSO} / \mathrm{H}_{2} \mathrm{O}, V: V=1: 9\right)$ in the presence of different concentrations of $\mathrm{NaClO}$ excited at $430 \mathrm{~nm}$ with that of $\mathbf{C 0}(10 \mu \mathrm{mol} / \mathrm{L})$ for comparison

Black lines: from bottom to top: $0.0,0.3,0.5,0.8,1.2,1.5,2.0,2.5,3.0$, $4.0,5.0,6.0,7.0,8.0,9.0,11.0,13.0,16.0$ and $18.0 \mu \mathrm{mol} / \mathrm{L} \mathrm{ClO}^{-}$; red line: $10 \mu \mathrm{mol} / \mathrm{L} \mathbf{C O}$. Inset: Plot of fluorescent intensity at $510 \mathrm{~nm}$ of $\mathbf{C} 2$ as a function of $\mathrm{ClO}^{-}$concentration; fluorescent photograph of $\mathbf{C 2}$ and $\mathrm{C2}+\mathrm{NaClO}$

To evaluate the specific nature of $\mathbf{C 2}$ toward hypochlorite anion, the influences of representative anions such as $\mathrm{NO}_{2}^{-}, \mathrm{AcO}^{-}, \mathrm{NO}_{3}^{-}, \mathrm{ClO}_{3}^{-}, \mathrm{F}^{-}, \mathrm{ClO}_{4}^{-}, \mathrm{HCO}_{3}^{-}$, $\mathrm{Cl}^{-}, \mathrm{PO}_{4}^{3-}, \mathrm{SCN}^{-}, \mathrm{IO}_{3}^{-}, \mathrm{HPO}_{4}^{2-}, \mathrm{Br}^{-}, \mathrm{HSO}_{3}^{-}$, $\mathrm{HSO}_{4}^{-}, \mathrm{I}^{-}$and $\mathrm{S}_{2} \mathrm{O}_{3}^{2-}$ were investigated (Figure 3). For all other anions, there were nearly no obvious changes of the fluorescence spectra observed. Moreover, reactive oxygen species (ROS) including hydrogen peroxide $\left(\mathrm{H}_{2} \mathrm{O}_{2}\right)$, 
hydroxyl radical $(\bullet \mathrm{OH})$, tert-butyl hydroperoxide (TBHP), superoxide $\left(\mathrm{O}_{2}^{-}\right)$and peroxynitrite $\left(\mathrm{ONOO}^{-}\right)$were also tested under the same conditions. As shown in Figure 3, probe $\mathbf{C 2}$ also responded to $\mathrm{H}_{2} \mathrm{O}_{2}$, but not so good as in the case of $\mathrm{ClO}^{-}$. With the concentration of $\mathrm{H}_{2} \mathrm{O}_{2}$ as $6 \times 10^{-5}$ $\mathrm{mol} / \mathrm{L}$, the emission intensity $\left(I / I_{0}-1\right)$ increased only by 7.5 times, much lower than the case with $2 \times 10^{-5} \mathrm{~mol} / \mathrm{L}$ $\mathrm{ClO}^{-}\left(I / I_{0}-1=80\right)$. Actually, only in the presence of hypochlorite, the strong green emission could be observed, indicating that hypochlorite could be conveniently detected with the aid of a normal UV lamp visually (as displayed in the inset fluorescence photograph in Figure 3). Furthermore, the response of $\mathbf{C 2}$ to $\mathrm{ClO}^{-}$was measured in the presence of other competitive species. Fortunately, the presence of other background species did not show any obvious disturbance, indicating that probe $\mathbf{C 2}$ had selective response toward hypochlorite anion over other anions and ROS examined here.

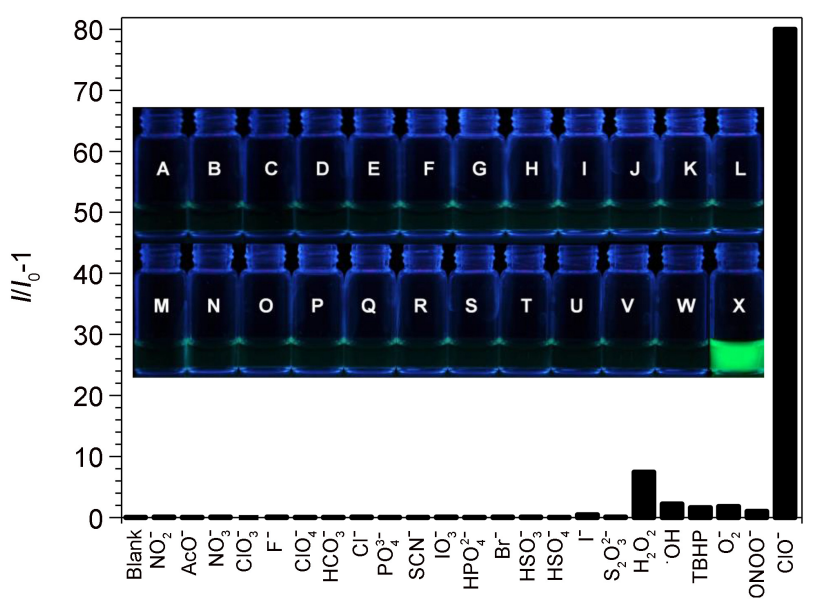

Figure 3 Emission intensity of $\mathbf{C 2}\left(10 \mu \mathrm{mol} / \mathrm{L}\right.$, in DMSO $/ \mathrm{H}_{2} \mathrm{O}$, $V: V=1: 9)$ in the presence of different anions $\left(\mathrm{ClO}^{-}, 20\right.$ $\mu \mathrm{mol} / \mathrm{L}$; ROS, $60 \mu \mathrm{mol} / \mathrm{L}$; other anions, $100 \mu \mathrm{mol} / \mathrm{L})$

Inset: fluorescent photograph of $\mathbf{C 2}$ to various anions. $\mathrm{A} \sim \mathrm{X}$ : blank, $\mathrm{NO}_{2}^{-}, \mathrm{AcO}^{-}, \mathrm{NO}_{3}^{-}, \mathrm{ClO}_{3}^{-}, \mathrm{F}^{-}, \mathrm{ClO}_{4}^{-}, \mathrm{HCO}_{3}^{-}, \mathrm{Cl}^{-}, \mathrm{PO}_{4}^{3-}$, $\mathrm{SCN}^{-}, \mathrm{IO}_{3}^{-}, \mathrm{HPO}_{4}^{2-}, \mathrm{Br}^{-}, \mathrm{HSO}_{3}^{-}, \mathrm{HSO}_{4}^{-}, \mathrm{I}^{-}, \mathrm{S}_{2} \mathrm{O}_{3}^{2-}, \mathrm{H}_{2} \mathrm{O}_{2}$, $\cdot \mathrm{OH}, \mathrm{TBHP}, \mathrm{O}_{2}^{-}, \mathrm{ONOO}^{-}$and $\mathrm{ClO}^{-}$

\subsection{Practical application}

The application of probe $\mathbf{C 2}$ to track intracellular $\mathrm{ClO}^{-}$ levels was also investigated by using a scanning microscopy. As shown in Figure 4c, the HeLa cells displayed apparent green fluorescence after staining with C2 (20 $\mu \mathrm{mol} / \mathrm{L}, 20 \mathrm{~min}$ ) and consequently incubated with $\mathrm{ClO}^{-}$ (50 $\mu \mathrm{mol} / \mathrm{L}, 20 \mathrm{~min})$. By contrast, in the control experiment, incubation of HeLa cells with only probe $\mathbf{C} 2$ gave no significant fluorescence (Figure 4a). The bright-field images demonstrated that the cells were viable during the imaging experiments (Figure $4 \mathrm{~b}$ and $4 \mathrm{~d}$ ). The fluorescence imaging results were in consistent with the observations in titration experiments, and indicated that probe $\mathbf{C} 2$ could penetrate the cell membrane and be used for imaging of $\mathrm{ClO}^{-}$in living cells and in vivo potentially.

To further evaluate its practical application, tap water was analyzed using the present hypochlorite-sensing sys-

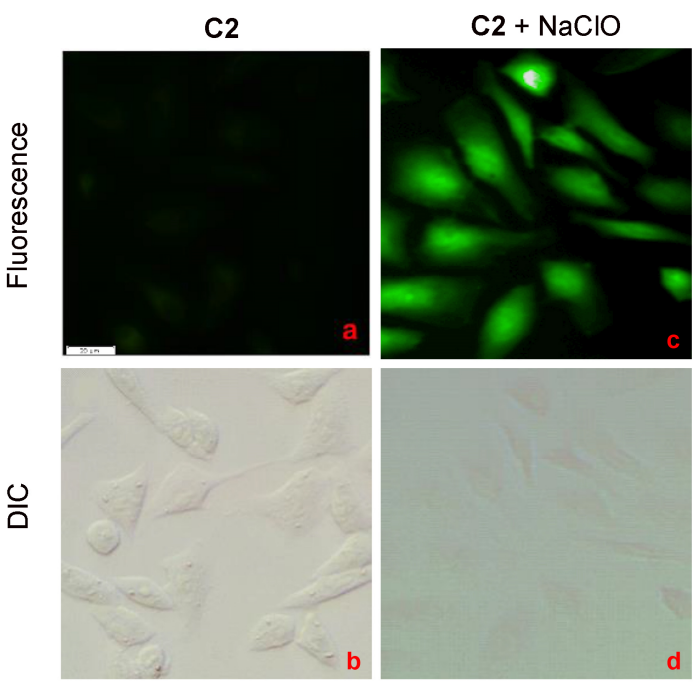

Figure 4 Fluorescence (a and c) and brightfield images (b and d) of cells

( $a$ and b) image of cells incubated with $\mathbf{C 2}(20 \mu \mathrm{mol} / \mathrm{L})$ for $20 \mathrm{~min}$; (c and d) fluorescence image of cells pre-treated with $\mathbf{C 2}(20 \mu \mathrm{mol} / \mathrm{L})$ for $20 \mathrm{~min}$ and then incubated with $\mathrm{ClO}^{-}(50 \mu \mathrm{mol} / \mathrm{L})$ for $20 \mathrm{~min}$. Scale bar: $20 \mu \mathrm{m}$

tem. Excitingly, even the addition of $50 \mu \mathrm{L}$ tap water led to marked emission increasement. Moreover, the fluorescent intensity changed continually with the increasing amount of tap water. Accordingly, standard addition method was utilized to determine the concentration of $\mathrm{ClO}^{-}$in the tap water samples and $\mathrm{ClO}^{-}$spiked tap samples, respectively. Firstly, the addition of $300 \mu \mathrm{L}$ of tap water led to marked increase $\left(I / I_{0}-1=16\right)$ in the emission intensity of the sensing system. According to the equation of linear regression in the inset of Figure 2, it could be calculated the concentration of tap water sample as $2.9 \times 10^{-5} \mathrm{~mol} / \mathrm{L}$, which was higher than the required concentrations $(8.4 \times$ $10^{-6} \mathrm{~mol} / \mathrm{L}$ ) in tap water set by the Standardization Administration of the People's Republic of China. Next, the $\mathrm{ClO}^{-}$spiked tap samples were investigated using the same method. Accordingly, the addition of tap water samples spiked with of $\mathrm{ClO}^{-}$(the final concentration was calculated to be $2.0 \times 10^{-5} \mathrm{~mol} / \mathrm{L}$ ) led to a significant increase $\left(I / I_{0}-1=24\right)$ in the fluorescence spectra and the total concentration of $\mathrm{ClO}^{-}$in this sample was calculated to be $5.0 \times 10^{-5} \mathrm{~mol} / \mathrm{L}$. Eliminating the $\mathrm{ClO}^{-}$in tap water, we calculated the spiked $\mathrm{ClO}^{-}$as $2.1 \times 10^{-5} \mathrm{~mol} / \mathrm{L}$, which was in good agreement with the true values. These results indicated that this novel probe could be used for quantitative analysis of $\mathrm{ClO}^{-}$levels potentially in environmental samples.

\subsection{Investigation of sensing mechanism}

Compound $\mathbf{C 2}$ was taken as an example to explore the sensing mechanism. The reaction of $\mathbf{C 2}$ with 20 equiv. $\mathrm{ClO}^{-}$was carried out in $\mathrm{CH}_{3} \mathrm{OH}-\mathrm{H}_{2} \mathrm{O}(V: V=9: 1)$ solution. After stirring at ambient temperature for $2 \mathrm{~h}$, the major product was purified by chromatography on a silica gel column. Characterized by ESI-MS spectrometry and ${ }^{1} \mathrm{H}$ NMR spectroscopy, it was found that the product from the reaction of $\mathbf{C 2}$ with $\mathrm{ClO}^{-}$was compound $\mathbf{C 0}$, in which the 
imine group was converted to an aldehyde group. The ESI-MS spectrum of $\mathbf{C 2}$ revealed a main peak at $\mathrm{m} / z$ 345.9 before $\mathrm{ClO}^{-}$was added to $\mathbf{C 2}$, corresponding to the species $[\mathbf{C 2}+\mathrm{H}]^{+}\left(m / z_{\text {calcd }}=345.2\right)$. After the addition of excess $\mathrm{ClO}^{-}$into the solution of $\mathbf{C 2}$, a new peak at about 269.8 appeared coinciding exactly with that for the species $[\mathbf{C O}+\mathrm{H}]^{+}\left(\mathrm{m} / \mathrm{z}_{\text {calcd }}=270.1\right)$, indicating the transformation from imine to aldehyde group. To further verify the nature of the oxidation reaction, the major reaction product was also underwent ${ }^{1} \mathrm{H}$ NMR analysis (Figure 5). For the isolated product from the reaction of $\mathbf{C 2}$ with $\mathrm{ClO}^{-}$(Figure $5 \mathrm{~b})$, the signals at $\delta 8.5$ ascribed to the $\mathrm{CH}=\mathrm{N}$ proton $\left(\mathrm{H}_{\mathrm{a}}\right)$ and the signals of proton on benzene vanished while a new signal at about $\delta 10.1$ (CHO proton) appeared, indicating that the $\mathrm{C}=\mathrm{N}$ bond of probe $\mathbf{C} \mathbf{2}$ transformed into aldehyde group from an oxidative cleavage reaction with $\mathrm{ClO}^{-}$. In fact, the corresponding ${ }^{1} \mathrm{H} \mathrm{NMR}$ spectrum of $\mathrm{C2}^{-} \mathrm{ClO}^{-}$ was the same as that of aldehyde $\mathbf{C O}$ (Figure 5c). Accordingly, we proposed the possible sensing mechanism of the present system as demonstrated in Scheme 3.

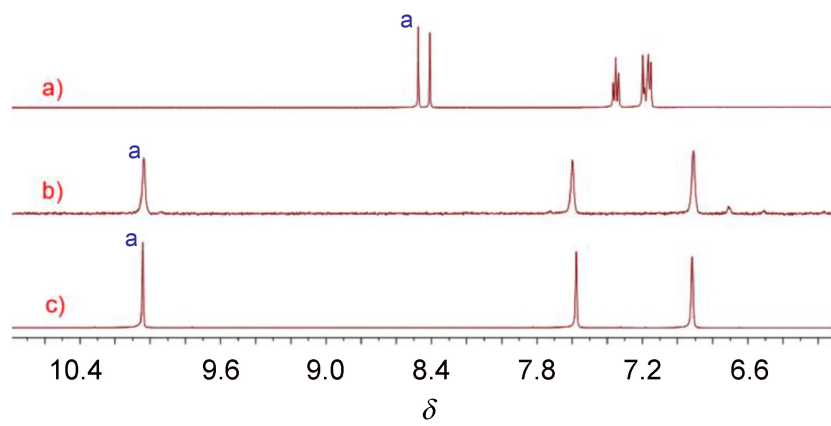

Figure $5{ }^{1} \mathrm{H}$ NMR spectra of $\mathbf{C 2}$ (a), the isolated resultant compound $\mathbf{C 2}-\mathrm{ClO}^{-}$(b) with that of $\mathbf{C 0}$ (c) for comparison in DMSO- $d_{6}$
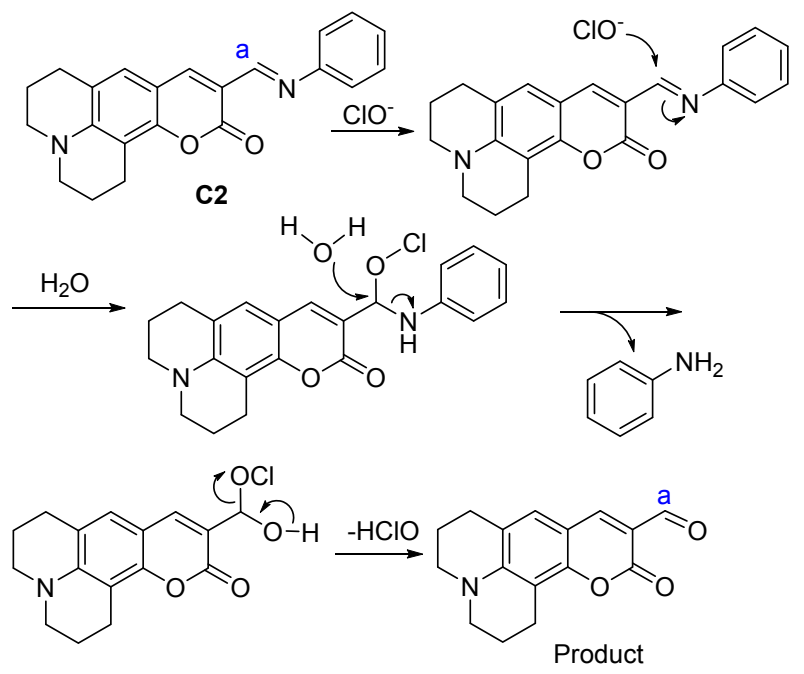

Scheme 3 Proposed sensing mechanism

\section{Conclusions}

In summary, two novel coumarin-type fluorescent probes (compounds $\mathbf{C 1}$ and $\mathbf{C 2}$ ) were synthesized for the rapid detection of $\mathrm{ClO}^{-}$by employing the special oxida- tion property of hypochlorite. Comparingly, probe $\mathbf{C 2}$ had much more excellent performance than $\mathbf{C 1}$ toward $\mathrm{NaClO}$. Upon the addition of $\mathrm{ClO}^{-}$to the solution of probe $\mathbf{C 2}$, the emission intensity increased by about 85 -fold and the fluorescence quantum yield increased from 0.02 to 0.73 . Meanwhile, the solution changed from non-fluorescence to strongly green fluorescence which could be easily distinguished by naked eyes with the aid of a normal UV lamp. Consequently, probe $\mathbf{C 2}$ could detect $\mathrm{ClO}^{-}$quantitatively with a detection limit as low as $1.8 \times 10^{-7} \mathrm{~mol} / \mathrm{L}$. The probe displayed extremely high selectivity for $\mathrm{ClO}^{-}$over other common anions and oxidants. Furthermore, probe C2 could be used for the successful bioimaging as well as analysis of $\mathrm{ClO}^{-}$levels in tap water.

\section{Experimental section}

\subsection{Materials and instrumentations}

All reagents were of analytical reagent grade and used without further purification. Deionized water was used in all experiments. Inorganic salts were purchased from Shanghai Chemical Reagent Co. (Shanghai, China). Ethanol was dried over and distilled from $\mathrm{Na}$ under an atmosphere of dry nitrogen. $N, N$-Dimethylfomamide (DMF) was dried over and distilled from $\mathrm{CaH}_{2}$ under an atmosphere of dry nitrogen.

The ${ }^{1} \mathrm{H}$ NMR and ${ }^{13} \mathrm{C}$ NMR spectra were measured on a Bruker500 spectrometer using tetramethylsilane (TMS; $\delta$ 0 ) as internal standard. Melting points were measured on a Beijing Taike XT-4 microscopy melting point apparatus, and the thermometer was uncorrected. Elemental analyses were performed by a CARLOERBA-1106 microelemental analyzer. The ESI mass spectra were measured on a Finnigan LCQ advantage mass spectrometer. Photoluminescence spectra were performed on a Hitachi F-4700 fluorescence spectrophotometer. The $\mathrm{pH}$ values were determined by using a DELTA 320 PH dollar.

\subsection{Synthesis of target compounds}

4.2.1 Synthesis of 10-oxo-2,3,5,6-tetrahydro- $1 H, 4 H$, 10H-11-oxa-3a-azabenzo[de] anthracene-9-carbaldehyde (C)

Compound $\mathbf{C 0}^{[8]}$ was readily synthesized according to the literature. Yellow solid, 83\% yield. ${ }^{1} \mathrm{H}$ NMR (500 $\left.\mathrm{MHz}, \mathrm{CDCl}_{3}\right) \delta: 10.06$ (s, 1H, CHO), 8.06 (s, 1H, ArH), $6.93(\mathrm{~s}, 1 \mathrm{H}, \mathrm{ArH}), 3.36\left(\mathrm{t}, J=10.0 \mathrm{~Hz}, 4 \mathrm{H}, 2 \mathrm{CH}_{2}\right), 2.86(\mathrm{t}$, $\left.J=7.5 \mathrm{~Hz}, 2 \mathrm{H}, \mathrm{CH}_{2}\right), 2.75\left(\mathrm{t}, J=10.0 \mathrm{~Hz}, 2 \mathrm{H}, \mathrm{CH}_{2}\right)$, $1.96 \sim 1.99\left(\mathrm{~m}, 4 \mathrm{H}, 2 \mathrm{CH}_{2}\right) ;{ }^{13} \mathrm{C} \mathrm{NMR}\left(125 \mathrm{MHz}, \mathrm{CDCl}_{3}\right)$ $\delta: 187.8,162.1,153.7,149.3,144.8,128.2,119.8,112.6$, 108.0, 106.0, 50.3, 49.9, 27.2, 20.8, 19.8; MS (ESI) $\mathrm{m} / \mathrm{z}$ (\%): $269.8\left([\mathrm{M}+\mathrm{H}]^{+}, 100\right), 270.9$ (18.0), 271.9 (2.1).

4.2.2 Synthesis of 10-oxo-2,3,5,6-tetrahydro- $1 H, 4 H$, 10H-11-oxa-3a-azabenzo[de] anthracene-9-carbaldehyde oxime (C1)

Compound C0 (161 mg, $0.6 \mathrm{mmol})$ and hybroxylamine hydrochloride ( $85 \mathrm{mg}, 1.2 \mathrm{mmol})$ in ethanol $(5 \mathrm{~mL})$ were stirred at room temperature overnight. After the reaction, 
the solvent was removed under reduced pressure. The resultant residue was purified by silica gel column chromatography (dichloromethane/ethyl acetate/methanol, $V$ : $V: V=35: 5: 1)$ to afford $\mathbf{C 1}$ as yellow solid $(107 \mathrm{mg}$, $63 \%$ yield). m.p. $196 \sim 198{ }^{\circ} \mathrm{C} ;{ }^{1} \mathrm{H}$ NMR $(500 \mathrm{MHz}$, DMSO-d $\left.d_{6}\right) \delta: 11.04(\mathrm{~s}, 1 \mathrm{H}, \mathrm{OH}), 8.04(\mathrm{~s}, 1 \mathrm{H}, \mathrm{ArH}), 7.98$ $(\mathrm{s}, 1 \mathrm{H}, \mathrm{ArH}), 7.14(\mathrm{~s}, 1 \mathrm{H}, \mathrm{ArH}), 3.28 \sim 3.35(\mathrm{~m}, 4 \mathrm{H}$, $\left.2 \mathrm{CH}_{2}\right), 2.70 \sim 2.78\left(\mathrm{~m}, 4 \mathrm{H}, 2 \mathrm{CH}_{2}\right), 1.85 \sim 1.90(\mathrm{~m}, 4 \mathrm{H}$, $\left.2 \mathrm{CH}_{2}\right) ;{ }^{13} \mathrm{C}$ NMR $\left(125 \mathrm{MHz}\right.$, DMSO- $\left.d_{6}\right) \delta: 160.7,151.6$, $146.8,143.4,138.9,126.5,119.2,110.8,108.0,105.7$, 49.8, 49.3, 27.2, 21.2, 20.3, 20.1; MS (ESI) $\mathrm{m} / \mathrm{z}$ (\%): 285.1 $\left(100,[\mathrm{M}+\mathrm{H}]^{+}\right), 286.1$ (18.4), 287.1 (2.2). Anal calcd for $\mathrm{C}_{16} \mathrm{H}_{16} \mathrm{~N}_{2} \mathrm{O}_{3} \mathrm{C}$ 67.59, H 5.67, N 9.85; found $\mathrm{C} 67.64, \mathrm{H}$ 5.29, N 9.99 .

4.2.3 Synthesis of 3-(phenylimino)methyl-10-oxo-2,3, 5,6-tetrahydro- $1 H, 4 H, 10 H$-11-oxa-3a-azabenzo[de]anthracene (C2)

The solution of aldehyde CO $(80.5 \mathrm{mg}, 0.3 \mathrm{mmol})$ in 5 $\mathrm{mL}$ of hot absolute ethanol was added into the solution of aniline (42 $\mathrm{mg}, 0.45 \mathrm{mmol}$ ) in $5 \mathrm{~mL}$ of absolute ethanol. The mixture was refluxed for $6 \mathrm{~h}$ to yield orange precipitate. The precipitate was filtrated and then recrystallized from ethanol to get compound $\mathbf{C 2}$ as orange solid $(65 \mathrm{mg}$, $62.5 \%$ yield). m.p. $225 \sim 228{ }^{\circ} \mathrm{C} ;{ }^{1} \mathrm{H}$ NMR $(500 \mathrm{MHz}$, DMSO- $\left.d_{6}\right) \delta: 8.50(\mathrm{~s}, 1 \mathrm{H}, \mathrm{ArH}), 8.44(\mathrm{~s}, 1 \mathrm{H}, \mathrm{ArH}), 7.39(\mathrm{t}$, $J=7.5 \mathrm{~Hz}, 2 \mathrm{H}, \mathrm{ArH}), 7.16 \sim 7.24(\mathrm{~m}, 4 \mathrm{H} \mathrm{ArH}), 2.69 \sim$ $2.75\left(\mathrm{~m}, 4 \mathrm{H}, 2 \mathrm{CH}_{2}\right), 1.85 \sim 1.91\left(\mathrm{~m}, 4 \mathrm{H}, 2 \mathrm{CH}_{2}\right), 1.13 \sim$ $1.18\left(\mathrm{~m}, 4 \mathrm{H}, 2 \mathrm{CH}_{2}\right) ;{ }^{13} \mathrm{C}$ NMR $\left(125 \mathrm{MHz}, \mathrm{DMSO}-d_{6}\right) \delta$ : $161.2,154.6,151.8,151.5,147.5,141.4,129.2,127.3$, $125.7,120.9,119.1,112.3,107.7,105.0,49.7,48.9,26.8$, 20.6, 19.6, 18.7; MS (ESI) $m / z(\%): 345.9\left(100,[\mathrm{M}+\mathrm{H}]^{+}\right)$, 347.1 (24.9), 371.9 (5.1). Anal calcd for $\mathrm{C}_{22} \mathrm{H}_{20} \mathrm{~N}_{2} \mathrm{O}_{2} \mathrm{C}$ 76.72, H 5.85, N 8.13; found C 76.90, H 5.66, N 8.21.

\subsection{Preparation of solutions of anions and ROS}

$1 \mathrm{mmol}$ of each inorganic salt $\left(\mathrm{NaNO}_{2}, \mathrm{NaOAc} \cdot 3 \mathrm{H}_{2} \mathrm{O}\right.$, $\mathrm{NaNO}_{3}, \mathrm{KClO}_{3}, \mathrm{NaF}, \mathrm{KClO}_{4}, \mathrm{NaHCO}_{3}, \mathrm{NaCl}, \mathrm{Na}_{3} \mathrm{PO}_{4}$, $\mathrm{KSCN}, \mathrm{NaIO}_{3}, \mathrm{Na}_{2} \mathrm{HPO}_{4} \bullet 12 \mathrm{H}_{2} \mathrm{O}, \mathrm{KBr}, \mathrm{NaHSO}_{3}, \mathrm{NaHSO}_{4}$, $\mathrm{KI}, \mathrm{Na}_{2} \mathrm{~S}_{2} \mathrm{O}_{3} \cdot 5 \mathrm{H}_{2} \mathrm{O}$ or $\mathrm{NaClO}$ ) was dissolved in deionized water $(10 \mathrm{~mL})$ to afford $1 \times 10^{-1} \mathrm{~mol} / \mathrm{L}$ aqueous solution. Stock solutions or generation of reactive oxygen species including hydrogen peroxide $\left(\mathrm{H}_{2} \mathrm{O}_{2}\right)$, hydroxyl radical $(\bullet \mathrm{OH})$, tert-butyl hydroperoxide (TBHP), superoxide $\left(\mathrm{O}_{2}^{-}\right)$, or peroxynitrite $\left(\mathrm{ONOO}^{-}\right)$were prepared according to the reported procedure. ${ }^{[9]}$ The stock solutions were diluted to desired concentrations with deionized water when needed.

\subsection{Fluorescence titration of $\mathrm{C} 1 / \mathrm{C} 2$ with $\mathrm{ClO}^{-}$}

A solution of $\mathbf{C 1}$ or $\mathbf{C 2}\left(1 \times 10^{-5} \mathrm{~mol} / \mathrm{L}\right)$ was prepared in HEPES/DMSO $\left(V: V=9: 1,10 \mathrm{mmol} \cdot \mathrm{L}^{-1}, \mathrm{pH}=7.4\right)$. Then $3.0 \mathrm{~mL}$ of the solution of $\mathbf{C 1}$ or $\mathbf{C 2}$ was placed in a quartz cell (10.0 mm width) and the fluorescence spectrum was recorded. The $\mathrm{NaClO}$ solution was introduced in portions and fluorescence intensity changes were recorded at room temperature each time (excitation wavelength: 430 $\mathrm{nm})$.
4.5 Fluorescence intensity changes of C2 with other anions and ROS

A solution of $\mathbf{C 2}\left(1 \times 10^{-5} \mathrm{~mol} / \mathrm{L}\right)$ was prepared in HEPES/DMSO $\left(V: V=9: 1,10 \mathrm{mmol} \cdot \mathrm{L}^{-1}, \mathrm{pH}=7.4\right)$. Then $3.0 \mathrm{~mL}$ of the solution of $\mathbf{C 2}$ was placed in a quartz cell $(10.0 \mathrm{~mm}$ width) and the fluorescence spectrum was recorded. Different anions or ROS solutions were introduced and the changes of the fluorescence intensity were recorded at room temperature each time (excitation wavelength: $430 \mathrm{~nm}$ ).

\subsection{Quantum yield calculation}

Quantum yield was determined according to the equation as follows:

$$
\Phi_{\mathrm{F}(\text { sample })}=\left[\frac{A_{\text {standard }}}{A_{\text {sample }}}\right]\left[\frac{F_{\text {sample }}}{F_{\text {standard }}}\right] \Phi_{\mathrm{F}(\text { standard })}
$$

$\Phi_{\mathrm{F}}$ is the fluorescence quantum yield, $A$ is the absorbance, and $F$ is the area under the corrected emission curve. Here, fluorescein was used as the standard, and the quantum yield of fluorescein in $0.1 \mathrm{~mol} \cdot \mathrm{L}^{-1} \mathrm{NaOH}$ was $0.90 .^{[10]}$

\subsection{Fluorescence imaging}

HeLa cells were seeded to the 24-well plates, the cells with an initial density of $5 \times 10^{4}$ cells $^{\bullet}$ well $^{-1}$ in 24-well plates were routinely maintained at $37{ }^{\circ} \mathrm{C}$ in a humidified $5 \% \mathrm{CO}_{2}$ atmosphere using DMEM (Dulbecco's modified eagle's medium) supplemented with $10 \%$ fetal bovine serum and $1 \%$ penicillin-streptomycin for $24 \mathrm{~h}$.

Fluorescence cell imaging was performed with an OLYMPUS IX73 scanning microscopy with an objective lens $(40 \times)$. Fluorescence images of HeLa cells were monitored at $460 \sim 490 \mathrm{~nm}$ for green channel. The data were analyzed using software package provided by OLYMPUS instruments. Cell imaging was then carried out after washing cells with phosphate-buffered saline (PBS, $10 \mathrm{mmol} \bullet$ $\mathrm{L}^{-1}, \mathrm{pH} 7.02$ ).

\subsection{Fluorescence spectra changes of C2 with tap} water

A solution of $\mathbf{C 2}\left(10^{-5} \mathrm{~mol} / \mathrm{L}\right)$ was prepared in HEPES/ DMSO $(V: V=9: 1,10 \mathrm{mmol} / \mathrm{L}, \mathrm{pH}=7.4)$. Fluorescence intensity changes of probe $\mathbf{C 2}$ were recorded before and after the addition of different amount of tap water (excitation wavelength: $430 \mathrm{~nm}$ ).

Supporting Information ${ }^{1} \mathrm{H}$ NMR and ${ }^{13} \mathrm{C}$ NMR spectra of compounds $\mathbf{C 0} \sim \mathbf{C 2}$, emission spectra of $\mathbf{C 0} \sim \mathbf{C 2}$ in different ratio of $\mathrm{DMSO} / \mathrm{H}_{2} \mathrm{O}$, the $\mathrm{pH}$ effect on the performance of $\mathbf{C 2}$, anti-interference test of $\mathbf{C 2}$, emission profile of $\mathbf{C 2}$ with different amount of tap water, ESI-mass of $\mathbf{C 2}$ and $\mathbf{C 2}+\mathrm{NaClO}$. The Supporting Information is available free of charge via the Internet at http://sioc-journal.cn/.

\section{References}

[1] (a) Sugiyama, S.; Kugiyama, K.; Aikawa, M.; Nakamura, S.; Ogawa, H.; Libby, P. Thromb. Vasc. Biol. 2004, 24, 1309. 
(b) Pattison, D. I.; Davies, M. J. Chem. Res. Toxicol. 2001, 14, 1453 .

(c) Steinbeck, M. J.; Nesti, L. J.; Sharkey, P. F.; Parvizi, J. J. Orthop. Res. 2007, 25, 1128.

(d) Aokl, T.; Munemorl, M. Anal. Chem. 1983, 55, 209.

[2] (a) Cui, K.; Zhang, D. Q.; Zhang, G. X.; Zhu, D. B. Tetrahedron Lett. 2010, 51, 6052.

(b) Hwang, J.; Choi, M. G.; Bae, J.; Chang, S.-K. Org. Biomol. Chem. 2011, 9, 7011.

(c) Kim, T.-II.; Park, S.; Choi, Y.; Kim, Y. Chem.-Asian J. 2011, 6, 1358.

(d) Li, G.; Ji, D. D.; Zhang, S. M.; Li, J. M.; Li, C.; Qiao, R. Z. Sens. Actuators, B 2017, 252, 127.

(e) Pang, L. F.; Zhou, Y. M.; Gao, W. L.; Song, H. H.; Wang, X.; Wang, Y. RSC Adv. 2016, 6, 105795.

(f) Zhang, P.; Wang, Y.; Chen, L.; Yin, Y. B. Microchim. Acta 2017, 184,3781 .

[3] (a) Zhang, R.; Song, B.; Yuan, J. L. Trends Anal. Chem. 2018, 99 , 1. (b) Liu, C.; Jiao, X. J.; He, S.; Zhao, L. C.; Zeng, X. S. Talanta 2017, 174, 234.

(c) Liu, S. R.; Wu, S. P. Org. Lett. 2013, 15, 878.

(d) Manjare, S. T.; Kim, J.; Lee, Y.; Churchill, D. G. Org. Lett. 2014, 16, 520

(e) Qu, Z. J.; Ding, J. X.; Zhao, M. Y.; Li, P. J. Photochem. Photobiol. A 2015, 299, 1.

(f) Zhang, Y. R.; Zhao, Z. M.; Miao, J. Y.; Zhao, B. X. Sens. Actuators, $B$ 2016, 229, 408.

(g) Zhang, Z.; Zheng, Y.; Hang, W.; Yan, X.; Zhao, Y. Talanta 2011, 85,779 .

(h) Shi, L.; Yang S.; Hong, H. J.; Li, Y.; Yu, H. J.; Shao, G.; Zhang, K.; Gong, S. Z. Anal. Chim. Acta 2020, 1094, 122.

(i) Shi, L.; Yu, H. J.; Zeng, X. Q.; Yang, S.; Gong, S. Z.; Xiang, H.; Zhang K.; Shao G. New J. Chem. 2020, 44, 6232.

(j) Wei, H. Q.; Zeng, R. J.; Wang, S. L.; Zhang, C. H.; Chen, S.; Zhang, P. S.; Chen, J. Mater. Chem. Front. 2020, 4, 862.

(k) Ren, J. Y.; Zhang, P. S.; Liu, H.; Zhang, C. H.; Gao, Y.; Cui, J. X.; Chen, J. Sens. Actuators, B 2020, 304, 127299.

(1) Zhang, P. S.; Wang, H.; Zhang, D.; Zeng, X. Y.; Zeng, R. J.; Xiao, L. H.; Tao, H. W.; Long, Y. F.; Yi, P. G.; Chen, J. Sens. Actuators, $B$ 2018, 255, 2223.

(m) Zhang, P. S.; Wang, H.; Hong, Y. X.; Yu, M. L.; Zeng, R. J.; Long, Y. F.; Chen, J. Biosens. Bioelectron. 2017, 99, 318.

(n) Huang, Y.; Zhang, P. S.; Gao, M.; Zeng, F.; Qin, A. J.; Wu, S. Z.; Tang, B. Z. Chem. Commun. 2016, 52, 7288.

[4] (a) Wang, J.; Long, L.; Xie, D.; Song, X. Sens. Actuators, B 2013, 177, 27.

(b) Wang, L.; Li, W. X.; Zhi, W. J.; Ye, D. D.; Wang, Y.; Ni, L.; Bao, X. Dyes Pigm. 2017, 147, 357.

(c) Wang, J.; Hu, L. J.; Shen, J.; Jiang, J. Q.; Yu, K. Y., Sun, R. G. Chin. J. Org. Chem. 2018, 38, 760 (in Chinese).
(王军, 虎良军, 申婧, 姜吉泉, 郁科勇, 孙荣国, 有机化学, 2018, 38, 760.)

(d) Dong, X. B.; Zhang, G. X.; Shi, J. B.; Wang, Y. C.; Wang, M.; Peng, Q.; Zhang, D. Q. Chem. Commun. 2017, 53, 11654.

(e) Acharyya, S.; Gharami, S.; Patra, L.; Mondal, T. K. J. Fluoresc. 2017, 27, 2051.

(f) Yang, T.; Guo, Z.; Shao, A.; Zhao, P.; Zhu, W. Chin. J. Appl. Chem. 2016, 33, 397 (in Chinese).

(杨婷婷，郭志前，邵安东，赵平，朱为宏，应用化学， 2016, 33, 397.)

(g) Hou, S. H.; Qu, Z. G.; Zhong, K. L.; Bian, Y. J.; Tang, L. J. Chin. J. Org. Chem. 2016, 36, 768 (in Chinese).

(侯淑华, 曲忠国, 钟克利, 边延江, 汤立军, 有机化学, 2016, 36, 768.)

(h) Wang, W. L.; Yan, Y. L.; Wang, Q. M. Chem. Lett. 2017, 46, 1605.

(i) Prabhu, J.; Velmurugan, K.; Zhang, Q.; Radhakrishnan, S.; Tang, L. J.; Nandhakumar, R. J. Photochem. Photobiol. A 2017, 337, 6.

(j) Zhang, M.; Xiao, H. F.; Han, Z. X.; Yang, L. Q.; Wu, X. Y. Chin. J. Org. Chem. 2018, 38, 926 (in Chinese).

(张敏, 肖慧丰, 韩志湘, 仰榴青, 吴向阳, 有机化学, 2018, 38, 926.)

(k) Liu, Z.; Peng, C. N.; Wang, Y.; Pei, M. S.; Zhang, G. Y. Org. Biomol. Chem. 2016, 14, 4260.

(1) Torawane, P.; Tayade, K.; Bothra, S.; Sahoo, S. K.; Singh, N.; Borse, A.; Kuwar, A. Sens. Actuators, B 2016, 222, 562.

[5] (a) Luo, J.; Xie, Z.; Lam, J. W. Y.; Cheng, L.; Chen, H.; Qiu, C.; Kwok, H. S.; Zhan, X.; Liu, Y.; Zhu, D.; Tang, B. Z. Chem. Commun. 2001, 37, 1740 .

(b) Chen, J. W.; Xie, Z. L.; Lam, J. W. Y.; Law, C. C. W.; Tang, B. Z. Macromolecules 2003, 36, 1108 .

(c) Wei, B.; Li, W. Z.; Zhao, Z. J.; Qin, A. J.; Hu, R. R.; Tang, B. Z. J. Am. Chem. Soc. 2017, 139, 5075 .

(d) Chen, J.; Law, C. C. W.; Lam, J. W. Y.; Dong, Y.; Lo, S. M. F.; Williams, I. D.; Zhu, D.; Tang, B. Z. Chem. Mater. 2003, 15, 1535.

(e) Zhao, Z.; Chen, S.; Lam, J. W. Y.; Jim, C. K. W.; Chan, C. Y. K.; Wang, Z.; Lu, P.; Deng, C.; Kwok, H.; Ma, Y.; Tang, B. Z. J. Phys. Chem. C 2010, 114, 7963.

[6] Zeng, Q.; Li, Z.; Dong, Y. Q.; Di, C. A.; Qin, A. J.; Hong, Y. N.; Ji, L.; Zhu, Z. C.; Jim Cathy, K. W.; Yu, G.; Li, Q. Q.; Li, Z. A.; Liu, Y. Q.; Qin, J. G.; Tang, B. Z. Chem. Commun. 2007, 43, 70.

[7] Erdemir, S.; Kocyigit, O.; Karakurt, S. Sens. Actuat., B 2015, 220, 381.

[8] Yuan, L.; Lin, W. Y.; Song, J. Z.; Yang, Y. T. Chem. Commun. 2011, 47,12691

[9] Chen, G.; Song, F.; Wang, J.; Yang, Z.; Sun, S.; Fan, J.; Qiang, X.; Wang, X.; Dou B.; Peng, X. J. Chem. Commun. 2012, 48, 2949.

[10] Williams, A. T. R.; Winfield, S. A.; Miller, J. N. Analyst 1983, 108, 1067.

(Li, L.; Fan, Y.) 